\title{
Removal of iron and manganese from drinking water supply
}

\author{
G. K. Khadse ${ }^{1}$ - P. M. Patni ${ }^{1}$ - P. K. Labhasetwar ${ }^{1}$
}

Received: 25 June 2015/Accepted: 4 August 2015/Published online: 14 August 2015

(C) Springer International Publishing 2015

\begin{abstract}
The water treatment plant at the Hingna industrial area receives raw water from Ambazari Lake and supplies drinking water to industrial area, after conventional treatment. The treated water was found to have a pungent odour and yellow colour, which in turn changed from a brown to black precipitate. The water becomes aesthetically unacceptable to consumers. It was observed that a blackish precipitate formation was due to the presence of iron and manganese in lake water, which was not completely removed during treatment. To remove iron and manganese from drinking water, treatment studies were carried out with chlorine and $\mathrm{KMnO}_{4}$ as oxidants. Alum and lime were added for coagulation and $\mathrm{pH}$ correction. Jar test studies revealed that treatment with potassium permanganate at $\mathrm{pH} 7.7-8.0$ was effective in the removal of iron, manganese and organics, which were responsible for causing colour and odour to water. The studies helped in improvements in water quality for safe drinking water supply.
\end{abstract}

Keywords Ambazari Lake · Water quality · Odour · Colour · Treatment

\section{Introduction}

Iron and manganese are common metallic elements bound in the Earth's crust. Water percolating through soil and rock can dissolve minerals containing iron and manganese

G. K. Khadse

gk_khadse@neeri.res.in; gkkhadse2007@rediffmail.com

1 National Environmental Engineering Research Institute, Nehru Marg, Nagpur 440020, India and hold them in solution (Dvorak and Skipton 2007) commonly found in groundwaters and some surface waters that have significant groundwater input (Casey 2009). They are mostly present in the soluble reduced divalent form as ferrous $\left(\mathrm{Fe}^{2+}\right)$ and manganous $\left(\mathrm{Mn}^{2+}\right)$ ions. The existence of dissolved iron and/or manganese in some deep lakes and reservoirs may be due to stratification, resulting in the development of anaerobic conditions in the bottom water zone and the dissolution of iron and manganese from floor deposits; the dissolved species are subsequently dispersed into the general water body by the annual overturn (Casey 2009). Iron and manganese are categorized as indicator parameters, which largely comprise constituents that are considered not to be of critical health significance. Their presence in water results in staining as well as offensive tastes and appearances (Keyser 1997). Waters containing iron and manganese, on exposure to air or oxygen, become cloudy and turbid due to the oxidation of iron and manganese to the $\mathrm{Fe}^{3+}$ and $\mathrm{Mn}^{4+}$ states, which form colloidal precipitates. The rates of oxidation are not rapid, and thus reduced forms can persist for some time in aerated waters (Sawyer and McCarty 1967). The presence of iron and manganese in water confront the water treatment engineer with a continuous challenge-that of finding better and more reliable removal methods (Willey 1963).

The removal of $\mathrm{Fe}$ and $\mathrm{Mn}$ comprise two stages: (a) an oxidation process in which the soluble forms of $\mathrm{Fe}$ and $\mathrm{Mn}$ are oxidized to form insoluble precipitates and (b) a solid separation process, in which the precipitated material is removed from the water stream (Casey 2009). The oxidation process may be a direct chemical reaction, where the electron acceptor may be oxygen or a strong oxidizing agent such as chlorine, chlorine dioxide, ozone or $\mathrm{KMnO}_{4}$. This method is particularly 
helpful when iron is combined with organic matter or when iron/manganese bacteria are present (McFarland and Dozier 2004). The oxidation/reduction reaction may be written as follows:

$$
\begin{aligned}
& 4 \mathrm{Fe}^{2+}+\mathrm{O}_{2}+8 \mathrm{OH}^{-}+2 \mathrm{H}_{2} \mathrm{O}=4 \mathrm{Fe}(\mathrm{OH})_{3}, \\
& 2 \mathrm{Fe}^{2+}+\mathrm{Cl}_{2}+6 \mathrm{OH}^{-}=2 \mathrm{Fe}(\mathrm{OH})_{3}+2 \mathrm{Cl}^{-} .
\end{aligned}
$$

The rate of chemical precipitation of iron and manganese is very much influenced by the $\mathrm{pH} / \mathrm{Eh}$ environment (Wolfe 1964). Chemically precipitated iron and manganese are removed in a rapid gravity or pressure filtration process.

Ambazari Lake is the raw water source for water treatment plant at Hingna industrial area near Nagpur. The treatment plant supplies water to various industrial units for domestic uses. The plant authority and consumers have been experiencing pungent odour and yellowish colour in the water even after conventional water treatment. The treated water initially did not show any discernible abnormality, but post-chlorination produces a yellow colour which turns to brown/black precipitate, rendering the water unacceptable to consumers. Therefore, an attempt was made to assess and identify the cause of the problem and suggest remedial measures for improvements in water quality.

\section{Materials and methods}

The Hingna industrial area is located at about $10 \mathrm{~km}$ from Nagpur in Maharashtra State in India. Water treatment plant at the Hingna industrial area receives raw water from Ambazari Lake, located at about $5 \mathrm{~km}$ and supplies drinking water to the industrial area after conventional treatment. The intake well is located towards the western side of Ambazari Lake. The mean depth of Ambazari Lake is about $7.55 \mathrm{~m}$ when it is completely filled. There is no multistage arrangement at intake for withdrawal of raw water. The raw water is drawn from about $2 \mathrm{~m}$ above the bottom of the lake throughout the year. The raw water from the intake well is pumped and carried to the treatment plant by M.S. pipe of about $3.2 \mathrm{~km}$ length.

The sampling locations were selected ensuring spatial distribution over the entire lake (Fig. 1). The details of water depth and depth of water samples are mentioned in Table 1. Surface and depth samples were collected to assess the overall quality of lake water. Depth water samples were collected from the same locations identified for surface water samples with the help of depth water sampler, so that vertical heterogeneities due to stratification may be looked into. The water quality of Ambazari Lake and water treatment plant was assessed in terms of physico-

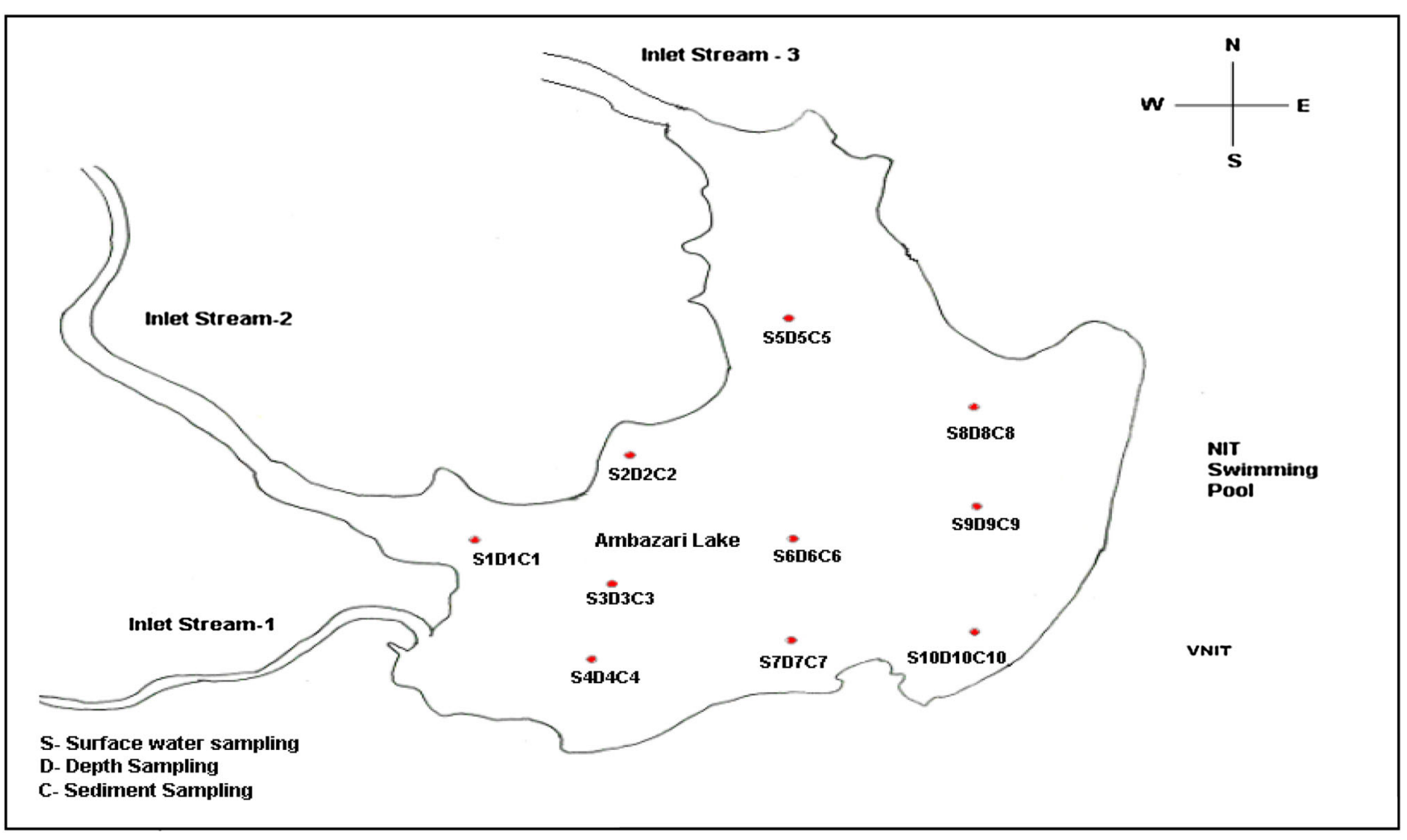

Fig. 1 Sampling locations in Ambazari Lake 
Table 1 Details of depth water samples

\begin{tabular}{lll}
\hline Sample no. & Water depth $(\mathrm{m})$ & Depth of water sample $(\mathrm{m})$ \\
\hline D-1 & 3.5 & 2.2 \\
D-2 & 4.0 & 3.0 \\
D-3 & 2.4 & 1.0 \\
D-4 & 3.0 & 2.1 \\
D-5 & 4.0 & 3.0 \\
D-6 & 4.5 & 3.5 \\
D-7 & 5.0 & 4.0 \\
D-8 & 4.5 & 3.5 \\
D-9 & 4.0 & 3.0 \\
D-10 & 2.2 & 1.5 \\
\hline
\end{tabular}

chemical parameters (Table 4) following the standard analytical methods (APHA 2005), to identify the water quality problem. The treatment studies were conducted for raw water for optimization of chemical doses.

\section{Treatment options}

\section{Chlorine}

Jar test experiments were carried out with increasing chlorine doses of 5,10 and $15 \mathrm{mg} / \mathrm{L}$. The alum doses applied were 20 and $30 \mathrm{mg} / \mathrm{L}$ (Table 5).

\section{Potassium permanganate}

The application of $\mathrm{KMnO}_{4}$ to remove taste, odour and oxidize iron and manganese is well known. Treatment studies were carried out using various combinations with different doses of $\mathrm{KMnO}_{4}$, lime and alum (Table 6).

\section{Results and discussion}

\section{Water quality of Ambazari Lake}

Water samples from Ambazari Lake were collected from different depths because the lower layer has a significantly decreased oxygen concentration compared with the upper layer due to stratification. When anoxic conditions occur in bottom sediments, various compounds such as ammonia, phosphate, sulphide, silicate, iron and manganese may increase in interstitial waters (through dissolution or reduction) and diffuse from the sediments into the lower water layer (Bartram and Balance 1996).

The $\mathrm{pH}$ of surface and depth water was found to be in the range of 7.2-7.9 and 6.9-7.7, respectively. The conductivity of $411-500 \mu \mathrm{S} / \mathrm{cm}$ was observed in the surface water, while in the range of $416-476 \mu \mathrm{S} / \mathrm{cm}$ in the depth water sample. Dissolved oxygen (DO) in surface water was observed in the range of $4.5-12.0 \mathrm{mg} / \mathrm{L}$, while in the depth water in the range of $1.7-8.7 \mathrm{mg} / \mathrm{L}$ which might be attributed to the turbulence usually seen due to anthropogenic and natural wind current over the lake surface. The total dissolved solids (TDS) in surface water were found to be low as compared to depth water $(450 \mathrm{mg} / \mathrm{L})$. This might be due to sludge deposition along with organic load at the bottom of the lake (Tables 2, 3).

The chemical oxygen demand (COD) of lake water was high and varied from 12 to $30 \mathrm{mg} / \mathrm{L}$, indicating that lake water was polluted by organic pollutants. The presence of organic matter is troublesome for many reasons including taste and odour, colour formation, oxygen depletion and interference with water treatment processes. However, significant difference was not observed in the physico-chemical quality of surface and depth water samples (Tables 2,3).

The metals, except iron and manganese, were found in very low concentration. Iron and manganese were found less in surface water of the lake as compared to depth water (Tables 2, 3). The Langelier Saturation Index (LSI) of water was negative, indicating that water was corrosive in nature.

\section{Water quality at treatment plant}

The water samples from cascade aerator (raw water), clariflocculator, rapid sand filter, and sump (treated water) were analysed monthly for the physico-chemical and bacteriological parameters and heavy metals (Table 4). The raw water has DO usually below $1 \mathrm{mg} / \mathrm{L}$. As the water trickles down and enters into the channel, the recovery of DO is up to $3 \mathrm{mg} / \mathrm{L}$. The pre-chlorination dose applied in the raw water channel is $3-4 \mathrm{mg} / \mathrm{L}$ to improve alum coagulation, controlling algal problems and ensuring effective post-chlorination. The reported alum dose was in the range of $20-30 \mathrm{mg} / \mathrm{L}$ in the clariflocculator. Two rapid gravity filters of $7.5 \mathrm{~m} \times 7.5 \mathrm{~m}$ size (sand size $0.84-1.19 \mathrm{~mm}$ ) run for $7-8 \mathrm{~h}$. The turbidity was found to be in the range of 1-4 NTU which indicated satisfactory performance of filters. The filtered water is disinfected (post-chlorination) using chlorine gas and also chlorine solution. The residual chlorine in the finished water was observed to be in the range of $0.2-0.5 \mathrm{mg} / \mathrm{L}$. At this juncture, the treated water produces yellow colour that in turns changes to brown/black at the consumers end, which is unacceptable to the users.

The raw water withdrawn through the cascade aerator has a characteristic sulphurous odour. This is due to hydrogen sulphide, which is produced at the bottom of the lake because of the biological activities related to 
Table 2 Physico-chemical characteristics of surface water samples from Ambazari Lake

\begin{tabular}{|c|c|c|c|c|c|c|c|c|c|c|c|}
\hline \multirow[t]{2}{*}{ S. no. } & \multirow[t]{2}{*}{ Parameters } & \multicolumn{10}{|c|}{ Sample code } \\
\hline & & S-1 & $\mathrm{S}-2$ & $\mathrm{~S}-3$ & S-4 & S-5 & S-6 & S-7 & S-8 & S-9 & S-10 \\
\hline 1 & Temperature $\left({ }^{\circ} \mathrm{C}\right)$ & 33.4 & 32.5 & 32.4 & 32.4 & 32.5 & 32.5 & 33 & 32 & 33 & 33 \\
\hline 2 & DO & 4.5 & 5.7 & 11.3 & 5.4 & 6.3 & 8.2 & 10.0 & 9.5 & 12.0 & 9.9 \\
\hline 3 & $\mathrm{pH}$ & 7.2 & 7.4 & 7.5 & 7.3 & 7.3 & 7.7 & 7.5 & 7.7 & 7.9 & 7.6 \\
\hline 4 & Conductivity $(\mu \mathrm{S} / \mathrm{cm})$ & 435 & 421 & 721 & 426 & 500 & 431 & 434 & 424 & 411 & 426 \\
\hline 5 & Total dissolved solid & 261 & 253 & 433 & 255 & 300 & 258 & 260 & 254 & 246 & 255 \\
\hline 6 & Turbidity (NTU) & 2.5 & 2.9 & 8.5 & 3.1 & 5.0 & 2.5 & 2.3 & 2.1 & 3.1 & 1.4 \\
\hline 7 & Total alkalinity due to $\mathrm{CaCO}_{3}$ & 124 & 128 & 136 & 124 & 152 & 132 & 116 & 116 & 116 & 120 \\
\hline 8 & Total hardness due to $\mathrm{CaCO}_{3}$ & 136 & 140 & 136 & 132 & 168 & 136 & 140 & 144 & 136 & 132 \\
\hline 9 & $\mathrm{Ca}$ hardness due to $\mathrm{CaCO}_{3}$ & 32 & 28 & 56 & 28 & 76 & 60 & 56 & 64 & 60 & 52 \\
\hline 10 & $\mathrm{Mg}$ hardness as $\mathrm{CaCO}_{3}$ & 104 & 122 & 80 & 104 & 92 & 76 & 84 & 80 & 76 & 80 \\
\hline 11 & Chloride as $\mathrm{Cl}$ & 124 & 124 & 124 & 124 & 124 & 124 & 120 & 124 & 124 & 124 \\
\hline 12 & Sodium as $\mathrm{Na}$ & 73 & 74 & 70 & 78 & 71 & 76 & 78 & 72 & 69 & 75 \\
\hline 13 & Potassium as $\mathrm{K}$ & 32 & 36 & 31 & 35 & 38 & 33 & 37 & 38 & 35 & 31 \\
\hline 14 & Nitrate as $\mathrm{N}$ & 0.72 & 0.76 & 0.76 & 0.70 & 1.5 & 1.1 & 1.1 & 1.0 & 0.9 & 0.7 \\
\hline 15 & Sulphate as $\mathrm{SO}_{4}$ & 9.1 & 6.5 & 7.6 & 6.8 & 6.6 & 7.6 & 7.5 & 8.1 & 7.5 & 13.7 \\
\hline 16 & Fluoride as $\mathrm{F}$ & 0.44 & 0.46 & 0.46 & 0.48 & 0.46 & 0.46 & 0.48 & 0.48 & 0.46 & 0.48 \\
\hline 17 & Phosphate as $\mathrm{PO}_{4}$ & 0.12 & 0.67 & 0.41 & 0.52 & 0.87 & 1.2 & 0.52 & 0.22 & 0.43 & 0.74 \\
\hline 18 & COD & 16 & 20 & 20 & 26 & 12 & 30 & 22 & 12 & 24 & 28 \\
\hline 19 & Iron as $\mathrm{Fe}$ & 0.39 & 1.13 & 0.27 & ND & 0.33 & 0.29 & 0.27 & 0.28 & 0.58 & 0.26 \\
\hline 20 & Manganese as $\mathrm{Mn}$ & 0.44 & 0.01 & 0.28 & 0.16 & 0.16 & 0.11 & 0.41 & 0.13 & 0.28 & 0.11 \\
\hline 21 & Langelier Index & -0.76 & -0.56 & -0.38 & -0.71 & -0.53 & -0.14 & -0.41 & -0.13 & 0 & -0.29 \\
\hline
\end{tabular}

All values except $\mathrm{pH}$, turbidity, conductivity and Langelier Index are in $\mathrm{mg} / \mathrm{L}$

$N D$ not detectable, $S$ surface water sample

vegetative and organic matter decay. The concentration of sulphide in raw water was in the range of $0.34-1.2 \mathrm{mg} / \mathrm{L}$. Similarly, DO was found to be between 0 and $3 \mathrm{mg} / \mathrm{L}$ in raw water. The DO of water in the clariflocculator and RSF were in the range of $2.4-5.5$ and $3.1-6.0 \mathrm{mg} / \mathrm{L}$, respectively, whereas when treated it increased up to $4.6-7.5 \mathrm{mg} /$ L. The $\mathrm{pH}$ and conductivity of all the samples were found to be in the range of $6.9-8.2$ and $380-478 \mu \mathrm{S} / \mathrm{cm}$, respectively. The turbidity of treated water was reduced to 1-3 NTU from 3 to 21 NTU in raw water. Sulphate, chloride, sodium and potassium were in the range of 6.8-29.47, $46-132,32-87$ and $4.3-50.0 \mathrm{mg} / \mathrm{L}$, respectively. Nitrate and phosphate in all stages of water treatment were $0.53-12.94$ and $0.03-2.0 \mathrm{mg} / \mathrm{L}$, respectively (Table 4).

The heavy metals, except iron and manganese, were below permissible limits in raw and treated water (BIS:10500 1991). During the months of May, June, July and August, iron and manganese contents in raw and treated water were higher (Figs. 2, 3). This may be attributed to dissolution of iron and manganese due to favourable conditions during summer. Thus, significant removal of iron and manganese could not be achieved during conventional treatment with the existing facilities.
In raw water, total coliforms (TC) range was $110-4400 \mathrm{CFU} / 100 \mathrm{~mL}$, while in treated water it was 10-295 CFU/100 mL. Similarly, faecal coliforms (FC) in raw water ranged from 102 to $1760 \mathrm{CFU} / 100 \mathrm{~mL}$. FCs in treated water were detected $(80 \mathrm{CFU} / 100 \mathrm{~mL}$ ) only in the month of November, which may be attributed to insufficient chlorination or optimum chlorine contact time (30-45 $\mathrm{min}$ ) after chlorination.

\section{Water quality issues}

Physico-chemical analysis of Ambazari Lake and treated water revealed the presence of iron and manganese in water. It was found that iron and manganese were partially removed during conventional treatment and appeared in treated water which developed yellowish to brown red colour. Simulation studies were performed in the laboratory using raw water and chlorinating it with different doses and changing contact period of reaction. It was observed that the colour development was a function of the applied chlorine dose and contact period. The rate of oxidation of manganous manganese and ferrous iron depends on chlorine dose and consequently the resultant colour. 
Table 3 Physico-chemical characteristics of depth water in Ambazari Lake

\begin{tabular}{|c|c|c|c|c|c|c|c|c|c|c|c|}
\hline \multirow[t]{2}{*}{ S. no. } & \multirow[t]{2}{*}{ Parameters } & \multicolumn{10}{|c|}{ Sample code } \\
\hline & & D-1 & D-2 & D-3 & D-4 & D-5 & D-6 & D-7 & D-8 & D-9 & D-10 \\
\hline 1 & Temperature $\left({ }^{\circ} \mathrm{C}\right)$ & 33 & 33 & 32.5 & 32 & 31.5 & 31.5 & 32.5 & 31.5 & 32 & 32.8 \\
\hline 2 & DO & 1.6 & 4.7 & 4.3 & 6.1 & 5.5 & 3.0 & 2.1 & 7.0 & 8.6 & 8.7 \\
\hline 3 & $\mathrm{pH}$ & 7.1 & 7.1 & 6.9 & 7.1 & 7.6 & 7.2 & 6.9 & 7.3 & 7.4 & 7.7 \\
\hline 4 & Conductivity $(\mu \mathrm{S} / \mathrm{cm})$ & 446 & 476 & 750 & 440 & 434 & 430 & 436 & 438 & 428 & 416 \\
\hline 5 & Total dissolved solid & 267 & 286 & 450 & 265 & 260 & 258 & 261 & 262 & 256 & 249 \\
\hline 6 & Turbidity (NTU) & 38.7 & 70.0 & 2.7 & 7.5 & 2.4 & 3.9 & 6.3 & 2.6 & 2.4 & 1.5 \\
\hline 7 & Total alkalinity due to $\mathrm{CaCO}_{3}$ & 128 & 144 & 132 & 116 & 128 & 124 & 128 & 124 & 116 & 116 \\
\hline 8 & Total hardness due to $\mathrm{CaCO}_{3}$ & 148 & 156 & 148 & 144 & 132 & 136 & 144 & 140 & 136 & 128 \\
\hline 9 & $\mathrm{Ca}$ hardness due to $\mathrm{CaCO}_{3}$ & 64 & 64 & 44 & 52 & 60 & 64 & 44 & 36 & 40 & 68 \\
\hline 10 & $\mathrm{Mg}$ hardness as $\mathrm{CaCO}_{3}$ & 82 & 92 & 104 & 92 & 72 & 72 & 100 & 104 & 96 & 60 \\
\hline 11 & Chloride as $\mathrm{Cl}$ & 124 & 124 & 124 & 120 & 128 & 124 & 128 & 120 & 128 & 128 \\
\hline 12 & Sodium as $\mathrm{Na}$ & 78 & 74 & 72 & 80 & 74 & 81 & 76 & 74 & 77 & 73 \\
\hline 13 & Potassium as $\mathrm{K}$ & 33 & 39 & 34 & 39 & 32 & 36 & 39 & 34 & 32 & 37 \\
\hline 14 & Nitrate as $\mathrm{N}$ & 1.2 & 1.0 & 0.8 & 0.9 & 1.2 & 1.0 & 0.7 & 0.9 & 0.9 & 0.8 \\
\hline 15 & Sulphate as $\mathrm{SO}_{4}$ & 4.9 & 6.9 & 5.7 & 9.6 & 7.4 & 6.6 & 6.5 & 8.0 & 5.8 & 8.0 \\
\hline 16 & Fluoride as $\mathrm{F}$ & 0.4 & 0.4 & 0.4 & 0.4 & 0.4 & 0.4 & 0.4 & 0.4 & 0.4 & 0.4 \\
\hline 17 & Phosphate as $\mathrm{PO}_{4}$ & 0.14 & 0.47 & 0.68 & 0.21 & 0.46 & 0.76 & 0.15 & 0.38 & 0.32 & 0.62 \\
\hline 18 & COD & 22 & 28 & 16 & 30 & 16 & 24 & 16 & 30 & 28 & 26 \\
\hline 19 & Iron as $\mathrm{Fe}$ & 0.46 & 4.0 & 0.28 & 0.08 & 0.27 & 0.24 & 0.34 & 0.30 & 0.77 & 0.32 \\
\hline 20 & Manganese as $\mathrm{Mn}$ & 0.70 & 0.34 & 0.41 & 0.57 & 0.13 & 0.26 & 0.26 & 0.19 & 0.57 & 0.19 \\
\hline 21 & Langelier Index & -0.77 & -0.73 & -1.01 & -0.82 & -0.24 & -0.65 & -0.99 & -0.65 & -0.51 & -0.15 \\
\hline
\end{tabular}

All values except $\mathrm{pH}$, turbidity, conductivity's and Langelier Index are in $\mathrm{mg} / \mathrm{L}$

$N D$ not detectable, $D$ depth water sample

Initially, a pale yellow colour developed and, on storage for $24 \mathrm{~h}$, a brown red precipitate settled down in the container. Hence, it was confirmed that the colouration in water is due to the presence of iron and manganese. It was observed that the high dose of chlorine $(15 \mathrm{mg} / \mathrm{L})$ coupled with excessive addition of lime resulted in the significant removal of $\mathrm{Fe}$ and $\mathrm{Mn}$ (Table 5). The $\mathrm{pH}$ of the test waters was 8.5 and above showing significant removal of iron and manganese. It is apparent that oxidation of iron and manganese depends on holdup time, $\mathrm{pH}$ and chlorine concentration. Thus, removal of iron and manganese using chlorine is not a practical proposition.

\section{Treatment options}

Treatment studies for removal of iron and manganese were conducted using Phipps and Bird jar testing machine by varying the doses of chlorine, lime and alum. The jar test experiments were conducted for different concentrations of chlorine, potassium permanganate, alum and lime at different $\mathrm{pH}$ values at various agitation and reaction times (Tables 5, 6).

\section{Chlorine}

The removal of iron and manganese was not significant at lower doses of chlorine ( 5 and $10 \mathrm{mg} / \mathrm{L}$ ). At $15 \mathrm{mg} / \mathrm{L}$ of chlorine dose with a contact period of $5 \mathrm{~h}$ at $\mathrm{pH}$ 8.0-8.9, there was significant removal of iron and manganese (Table 5). It is apparent that oxidation of iron and manganese depends on the holdup time, $\mathrm{pH}$ and chlorine concentrations. Thus, removal of iron and manganese using chlorine is not practically recommended.

When chlorine is used as the oxidizing agent, excess chlorine remains in the treated water. If the particle filter is made of calcite, sand, anthracite or aluminium silicate, a minimum amount of chlorine should be used to avoid the unpleasant taste that results from excess chlorine. An activated carbon filter removes excess chlorine, as well as small quantities of iron/manganese particles. Chlorine oxidizes iron best at a $\mathrm{pH}$ of 6.5-7.5. Chlorine should not be used for high levels of manganese, because manganese requires a $\mathrm{pH}$ higher than 9.5 for complete oxidation. 
Table 4 Water quality in water treatment plant

\begin{tabular}{|c|c|c|c|c|c|}
\hline S. no. & Parameters & Raw water & Clariflocculator & RSF & Treated water \\
\hline \multicolumn{6}{|c|}{ Physico-chemical } \\
\hline 1 & Temperature $\left({ }^{\circ} \mathrm{C}\right)$ & $27-35$ & $22-31$ & $23-31$ & $21.5-33$ \\
\hline 2 & DO & $0-3.0$ & $2.4-5.5$ & $3.1-6.0$ & $4.6-7.5$ \\
\hline 3 & $\mathrm{pH}$ & $7-8.2$ & $7.2-7.69$ & $7.0-7.9$ & $6.9-7.8$ \\
\hline 4 & Conductivity $(\mu \mathrm{S} / \mathrm{cm})$ & $380-478$ & $380-437$ & $384-448$ & $390-437$ \\
\hline 5 & Total dissolved solid & $222-276$ & $238-262$ & $230-265$ & $234-262$ \\
\hline 6 & Turbidity (NTU) & $3-21$ & $2-4$ & $1-4$ & $1-3$ \\
\hline 7 & Total alkalinity due to $\mathrm{CaCO}_{3}$ & $108-216$ & $100-116$ & $96-136$ & 88-204 \\
\hline 8 & Total hardness due to $\mathrm{CaCO}_{3}$ & 80-192 & $136-160$ & $84-160$ & $84-160$ \\
\hline 9 & $\mathrm{Ca}$ hardness due to $\mathrm{CaCO}_{3}$ & $32-104$ & $72-88$ & $36-112$ & $32-96$ \\
\hline 10 & $\mathrm{Mg}$ hardness as $\mathrm{CaCO}_{3}$ & $32-100$ & $48-88$ & $44-72$ & $44-78$ \\
\hline 11 & Chloride as $\mathrm{Cl}$ & $46-132$ & $48-128$ & $48-125$ & $52-124$ \\
\hline 12 & Sodium as $\mathrm{Na}$ & $39-84$ & $32-78$ & $41-83$ & $41.7-87$ \\
\hline 13 & Potassium as $\mathrm{K}$ & $5.3-4.7$ & $9-50$ & $5-47$ & $4.3-41$ \\
\hline 14 & Nitrate as $\mathrm{N}$ & $0.7-7.0$ & $0.7-4.0$ & $0.6-12.94$ & $0.53-7.1$ \\
\hline 15 & Sulphate as $\mathrm{SO}_{4}$ & $6.8-22.15$ & $16-29.47$ & $9.34-23$ & $7-20.1$ \\
\hline 16 & Fluoride as $\mathrm{F}$ & $0.46-0.50$ & $0.46-0.50$ & $0.48-0.5$ & $0.40-0.50$ \\
\hline 17 & Phosphate as $\mathrm{PO}_{4}$ & $0.12-2.0$ & $0.12-0.46$ & $0.03-1.29$ & $0.06-0.93$ \\
\hline 18 & COD mg/L & $9.0-20$ & $2-10$ & $2-6$ & $1-2$ \\
\hline 19 & BOD mg/L & $1.7-2.8$ & - & - & $0-1.7$ \\
\hline 20 & Iron as $\mathrm{Fe}$ & $0.08-1.51$ & $0.50-0.64$ & $0.10-1.07$ & $0.02-0.8$ \\
\hline 21 & Manganese as Mn & $0.23-1.7$ & $0.39-0.75$ & $0.05-2.37$ & $0.08-0.70$ \\
\hline 22 & Sulphide as $\mathrm{S}$ & $0.34-1.20$ & $0.20-0.26$ & $0.26-0.90$ & $0.05-0.50$ \\
\hline 23 & Langelier Index & -0.69 to +8.21 & -0.14 to -0.71 & -0.12 to -0.66 & -0.94 to +0.1 \\
\hline \multicolumn{6}{|c|}{ Bacteriology } \\
\hline 24 & $\mathrm{TC}(\mathrm{CFU} / 100 \mathrm{~mL})$ & $110-4400$ & - & - & 10-295 \\
\hline 25 & $\mathrm{FC}(\mathrm{CFU} / 100 \mathrm{~mL})$ & $102-1760$ & - & - & ND-80 \\
\hline
\end{tabular}

All values except $\mathrm{pH}$, turbidity, conductivity and Langelier Index are in $\mathrm{mg} / \mathrm{L}$

$R S F$ rapid sand filter, $N D$ not detectable, $C F U$ colony forming unit

Fig. 2 Concentration of iron in raw and treated water of treatment plant (the points represent a single point)

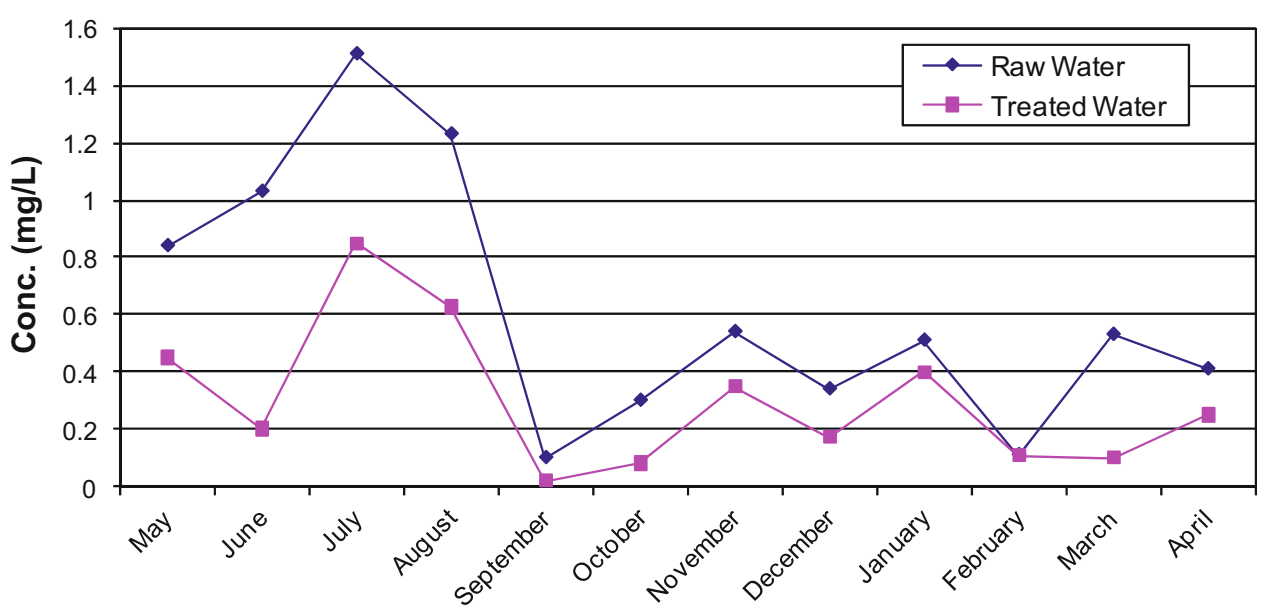

May 2006 - April 2007 

manganese in raw and treated water of the treatment plant (the points represent a single point)
Fig. 3 Concentration of

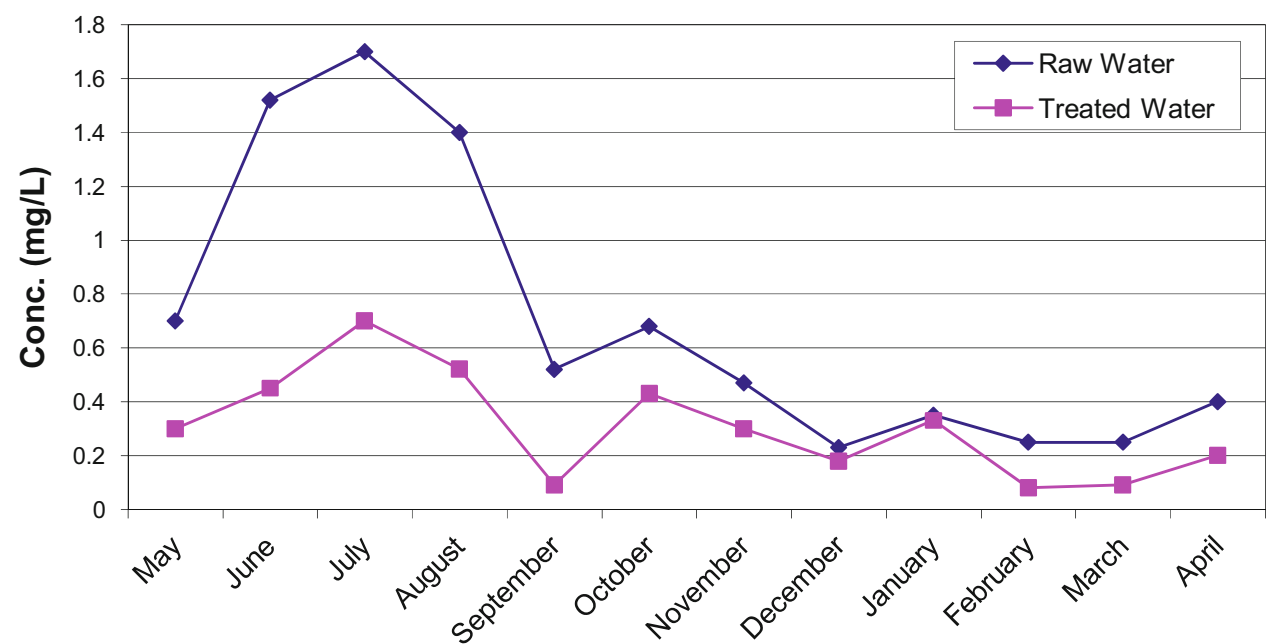

May 2006 - April 2007

Table 5 Treatment studies with chlorine, lime and alum-iron and manganese removal

\begin{tabular}{ccccccc}
\hline S. No. & $\begin{array}{l}\text { Chlorine } \\
(\mathrm{mg} / \mathrm{L})\end{array}$ & $\begin{array}{l}\text { Alum } \\
(\mathrm{mg} / \mathrm{L})\end{array}$ & $\begin{array}{l}\text { Lime } \\
(\mathrm{mg} / \mathrm{L})\end{array}$ & PH & $\begin{array}{l}\text { Iron } \\
(\mathrm{mg} / \mathrm{L})\end{array}$ & $\begin{array}{l}\text { Manganese } \\
(\mathrm{mg} / \mathrm{L})\end{array}$ \\
\hline Control & 0 & 0 & 0 & 7.4 & 0.8 & 0.7 \\
1 & 5 & 20 & 20 & 7.4 & 0.7 & 0.7 \\
2 & 5 & 20 & 40 & 7.5 & 0.6 & 0.7 \\
3 & 5 & 20 & 60 & 7.5 & 0.6 & 0.7 \\
4 & 5 & 20 & 80 & 7.8 & 0.5 & 0.7 \\
5 & 5 & 20 & 100 & 7.9 & 0.5 & 0.6 \\
Control & 0 & 0 & 0 & 7.2 & 0.8 & 0.7 \\
1 & 10 & 30 & 20 & 7.3 & 0.6 & 0.6 \\
2 & 10 & 30 & 40 & 7.5 & 0.5 & 0.5 \\
3 & 10 & 30 & 60 & 7.5 & 0.4 & 0.5 \\
4 & 10 & 30 & 80 & 7.6 & 0.3 & 0.5 \\
5 & 10 & 30 & 100 & 7.7 & 0.3 & 0.5 \\
Control & 0 & 0 & 0 & 7.4 & 0.8 & 0.7 \\
1 & 15 & 30 & 40 & 7.5 & 0.1 & 0.25 \\
2 & 15 & 30 & 80 & 8.0 & 0.1 & 0.14 \\
3 & 15 & 30 & 120 & 8.3 & 0.08 & 0.08 \\
4 & 15 & 30 & 160 & 8.6 & 0.05 & 0.06 \\
5 & 15 & 30 & 200 & 8.9 & 0.03 & 0.05 \\
\hline As & 5 & & & & 0.3 & 0.3 \\
\hline
\end{tabular}

As per BIS (10500: 1991), desirable and permissible limits for $\mathrm{Fe}$ and $\mathrm{Mn}$ in drinking water are 0.3, 1.00 .1 and $0.3 \mathrm{mg} / \mathrm{L}$ respectively

\section{Potassium permanganate}

In this test, $\mathrm{KMnO}_{4}$ was added in varying doses along with a constant dose of alum and lime $(20 \mathrm{mg} / \mathrm{L})$. The $\mathrm{pH}$ increased slightly from 7.4 to 7.6. The brownish/blackish colour flocks formed, settled rapidly and the supernatant did not have colour at $1 \mathrm{mg} / \mathrm{L}$ dose of $\mathrm{KMnO}_{4}$. The test was repeated with an increased dose $(2.1-2.5 \mathrm{mg} / \mathrm{L})$ of $\mathrm{KMnO}_{4}$. Complete removal of iron was obtained at $2.5 \mathrm{mg} / \mathrm{L}$ dose of $\mathrm{KMnO}_{4}$ and with alum and lime dose of $20 \mathrm{mg} / \mathrm{L}$.

In another set of experiment, doses of lime were increased up to $80 \mathrm{mg} / \mathrm{L}$, whereas $\mathrm{KMnO}_{4}(2 \mathrm{mg} / \mathrm{L})$ and alum (20 mg/L) doses were constant. The $\mathrm{pH}$ was raised up to 8.0 and it was observed that iron and manganese were removed completely. Similarly, in another set, $\mathrm{KMnO}_{4}$ $(2.5 \mathrm{mg} / \mathrm{L})$ and lime $(20 \mathrm{mg} / \mathrm{L})$ doses were kept constant and alum doses were increased from 15 to $35 \mathrm{mg} / \mathrm{L}$, wherein iron and manganese were removed remarkably well (Table 6).

The chemical must be in the water for at least $20 \mathrm{~min}$ for oxidation, and for more time if the water contains colloidal iron/manganese. After solid particles had formed, they were filtered with a sand filter. Addition of alum improves filtration by causing larger particles to form. Not only does 
Table 6 Treatment studies with $\mathrm{KMnO}_{4}$, lime and alum for removal of $\mathrm{Fe}$ and $\mathrm{Mn}$

\begin{tabular}{|c|c|c|c|c|c|c|}
\hline S. No. & $\mathrm{KMnO}_{4}(\mathrm{mg} / \mathrm{L})$ & Alum (mg/L) & Lime $(\mathrm{mg} / \mathrm{L})$ & $\mathrm{PH}$ & $\mathrm{Fe}(\mathrm{mg} / \mathrm{L})$ & $\mathrm{Mn}(\mathrm{mg} / \mathrm{L})$ \\
\hline Control & 0 & 0 & 0 & 7.4 & 0.8 & 0.7 \\
\hline 1 & 0 & 20 & 20 & 7.6 & 0.8 & 0.4 \\
\hline 2 & 0.2 & 20 & 20 & 7.6 & 0.7 & 0.4 \\
\hline 3 & 0.5 & 20 & 20 & 7.6 & 0.6 & 0.4 \\
\hline 4 & 0.8 & 20 & 20 & 7.6 & 0.4 & 0.3 \\
\hline 5 & 1.0 & 20 & 20 & 7.6 & 0.2 & 0.3 \\
\hline Control & 0 & 0 & 0 & 7.6 & 0.8 & 0.7 \\
\hline 6 & 2.1 & 20 & 20 & 7.7 & 0.4 & 0.2 \\
\hline 7 & 2.2 & 20 & 20 & 7.6 & 0.3 & 0.16 \\
\hline 8 & 2.3 & 20 & 20 & 7.6 & 0.2 & 0.10 \\
\hline 9 & 2.4 & 20 & 20 & 7.6 & 0.1 & 0.08 \\
\hline 10 & 2.5 & 20 & 20 & 7.6 & ND & ND \\
\hline Control & 0 & 0 & 0 & 7.4 & 0.8 & 0.7 \\
\hline 11 & 2.0 & 20 & 40 & 7.6 & 0.2 & 0.3 \\
\hline 12 & 2.0 & 20 & 50 & 7.7 & 0.2 & 0.3 \\
\hline 13 & 2.0 & 20 & 60 & 7.8 & 0.1 & 0.1 \\
\hline 14 & 2.0 & 20 & 70 & 7.9 & ND & ND \\
\hline 15 & 2.0 & 20 & 80 & 8.0 & ND & ND \\
\hline Control & 0 & 0 & 0 & 7.4 & 0.8 & 0.7 \\
\hline 16 & 2.5 & 15 & 20 & 7.6 & 0.4 & 0.3 \\
\hline 17 & 2.5 & 20 & 20 & 7.7 & 0.2 & 0.15 \\
\hline 18 & 2.5 & 25 & 20 & 7.7 & 0.2 & 0.10 \\
\hline 19 & 2.5 & 30 & 20 & 7.6 & 0.08 & 0.08 \\
\hline 20 & 2.5 & 35 & 20 & 7.5 & ND & 0.05 \\
\hline
\end{tabular}

As per BIS (10500: 1991), desirable and permissible limits for Fe and Mn in drinking water are 0.3, 1.0 and 0.1 and $0.3 \mathrm{mg} / \mathrm{L}$ respectively the form of the iron and manganese matter, but the amount of the metal present as well as hardness, temperature and $\mathrm{pH}$ are also key factors.

\section{Related issues}

\section{Pre-treatment}

Pre-oxidation with free chlorine is carried out for control of tastes and odours, algal control, oxidation of $\mathrm{Fe}$ and $\mathrm{Mn}$ and disinfection. It also improves the filterability of water and produces lower filtered water particle counts. Feeding chlorine ahead of the $\mathrm{KMnO}_{4}$ can make the process more economical. $\mathrm{Ca}(\mathrm{OH})_{2}$ addition may be necessary to achieve the desired $\mathrm{pH}$ level or to remove $\mathrm{CO}_{2}$.

\section{Maintenance}

Tests should be conducted at least monthly on samples of water entering the filter to ensure that $\mathrm{Fe}$ and $\mathrm{Mn}$ is in their insoluble oxidized states and to verify $\mathrm{KMnO}_{4}$ dosages. Backwashing should be done in accordance with the media.
System pressure and flow rate checks should also be performed to verify backwashing capabilities along with routine maintenance checks.

The factors that may inhibit the attainment of low residual iron and/or manganese concentrations by chemical precipitation include the following:

- Some of the dissolved iron may be sequestered by complexation with silica or humic substances, thereby retarding or preventing its oxidation.

- The natural $\mathrm{pH}$ of the water may be too low.

- The use of chlorine and $\mathrm{KMnO}_{4}$ prevents any microbially generated oxidation.

- The colloidal nature of the chemical precipitates may lead to carryover in the treated water.

\section{Filter backwashing}

The accumulated deposits of iron and/or manganese in filters are removed by backwashing with a reverse flow of water or by a combination of water and air. The required frequency of backwashing is a function of the iron/manganese concentrations to be removed, the applied filtration 
rates and the filter media size. It is reported (Mouchet $1992)$ that coarse $(>1 \mathrm{~mm})$ filter media, operated in a biooxidation mode, have a high retention capacity (1-5 kg Fe or $\mathrm{Mn} / \mathrm{m}^{2}$ ). Backwashing is typically initiated when the head loss across the filter has reached a set point value.

\section{Advantages of $\mathrm{KMnO}_{4}$ treatment in $\mathrm{Fe}$ and $\mathrm{Mn}$ removal from drinking water supply}

$\mathrm{KMnO}_{4}$ treatment is an effective and reliable treatment option in removal of $\mathrm{Fe}$ and $\mathrm{Mn}$ from drinking water supply.

\section{Disadvantages of $\mathrm{KMnO}_{4}$ treatment in $\mathrm{Fe}$ and $\mathrm{Mn}$ removal from drinking water supply}

Regular monitoring of treatment performance is required to ensure proper dosing of $\mathrm{KMnO}_{4}$ (bench-scale tests are required to determine the exact dosage). Sufficient pressure and flow rate are required for backwashing. Proper disposal of backwash material is also to be ensured. The dosage needs to be carefully controlled so that the permanganate residual does not remain in the water. Sufficient contact time must be provided to exhaust the permanganate residual before reaching the distribution system.

\section{Conclusion}

Ambazari Lake water had pungent odour and yellowish colour in the raw and treated water even after conventional treatment. Water quality assessment revealed that the colour development and brown/blackish precipitate formation were due to the presence of iron and manganese. Removal of iron and manganese is based on their ease of oxidation and precipitation at higher $\mathrm{pH}$. Coagulation is needed to facilitate better setting. Treatability studies were carried out with chlorine and $\mathrm{KMnO}_{4}$ as oxidants. Alum and lime were added for coagulation and $\mathrm{pH}$ correction. Jar test experiments during treatability studies revealed that treatment with potassium permanganate at $\mathrm{pH}$ 7.7-8.0 was effective in the removal of iron, manganese and organics, which are responsible for causing colour and odour to water. The rate of chemical precipitation of iron and manganese is highly dependent on $\mathrm{pH}$ and also requires a highly aerobic environment. The oxidation step may be carried out by aeration or more usually by use of a strong oxidant such as chlorine or, where manganese removal is required, by $\mathrm{KMnO}_{4}$.

\section{Compliance with ethical standards}

Conflict of interest No conflict of interest.

\section{References}

APHA, AWWA and WEF (2005) Standard methods for the examination of water and waste water, 21st edn. American Public Health Association, New York

Bartram J, Balance R (1996) Water quality monitoring - a practical guide to the design and implementation of freshwater quality studies and monitoring programmes. In: Jamie B, Richard B (eds) Published on behalf of United Nations Environment Programme and the World Health Organization. (C1996 UNEP/ WHO. ISBN 0419223207 (Hbk) 0419217304 (Pbk)

BIS:10500 (1991) Bureau of Indian Standards (BIS), guidelines for drinking water quality standards. Manak Bhavan, 9 Bahadurshah Zafar Marg, New Delhi

Casey TJ (2009) Iron and manganese in water: Occurrence, drinking water standards, treatment options. Aquavarra Research Publications Water Engineering Papers Aquavarra Research Limited, 22a brook field avenue, Blackrock, County Dublin, Ireland

Dvorak BI, Skipton SO (2007) Drinking water: iron and manganese. Neb Guide published by University of Nebraska-Lincoln Extension, Institute of Agriculture and Natural Resources

Keyser SL (1997) Iron and manganese in drinking water. UCD EXTOXNET FAQ Team. http://extoxnet.orst.edu/faqs/safe drink/iron.htm. Accessed June 1997

McFarland ML, Dozier MC (2004) drinking water problems: iron and manganese. Texas Cooperative Extension. The Texas A\&M University System

Mouchet P (1992) From conventional to biological removal of iron and manganese in France. JAWWA 84(4):158-167

Sawyer CN, McCarty PL (1967) Chemistry for sanitary engineers. McGraw-Hill Book Company, New York

Willey BF (1963) Iron and manganese removal with potassium permanganate. JAWWA 55(6):1963

Wolfe RS (1964) Iron and manganese bacteria. In: Heukelekian H, Dondero NC (eds) Principles and applications in aquatic microbiology. Wiley, New York 